\title{
RADIOCARBON CHRONOLOGY OF THE SHIGIR AND GORBUNOVO ARCHAEOLOGICAL BOG SITES, MIDDLE URALS, RUSSIA
}

\author{
Natalia E Zaretskaya ${ }^{1} \bullet$ Sönke Hartz ${ }^{2}$ Thomas Terberger $^{3} \bullet$ Svetlana N Savchenko $^{4} \bullet$ \\ Mikhail G Zhilin ${ }^{5}$
}

\begin{abstract}
Two well-known archaeological sites, the peat bogs of Shigir and Gorbunovo (Middle Urals, Russia), have been radiocarbon dated (61 conventional and accelerator mass spectrometry [AMS] dates from various natural and artifact samples). For the first time, a detailed chronology of Early to Late Mesolithic and Early Neolithic occupation for this region has been obtained, and a paleoenvironmental history reconstructed. Based on these results, we propose that the Mesolithic settlement of the Middle Urals region started in the early Holocene, at the same time as in central and eastern Europe.
\end{abstract}

\section{INTRODUCTION}

In the Middle Urals, archaeological finds from peat bogs have been well known since the end of the 19th century. The most famous sites are the Shigir and Gorbunovo peat bogs, located between the cities of Ekaterinburg and Nizhniy Tagil (Figure 1A). They are well known because of extraordinary Stone and Bronze Age artifacts, made from wood, bone, antler, and other organic materials. Until recently, almost no absolute dates for the earliest human settlement of these bogs were available. Before excavations at Gorbunovo were started in 2008 by Mikhail Zhilin and Svetlana Savchenko, all Mesolithic sites in the Eastern Urals region had been traditionally assigned to the late phase of this period. It was thought that during the Early and Middle Mesolithic the region was not suitable for settlement (Serikov 2000). However, there was no scientific proof for this assumption. Paleoenvironmental data (Khotinsky 1977) indicated that climatic and vegetational changes were very similar in eastern Europe and the Eastern Urals. Several published radiocarbon dates, including 3 dates from the Great Shigir idol (GIN-9467/1: $8680 \pm 140$ BP, GIN-9467/2: $8750 \pm 60$ BP, LE-5303: $8620 \pm 70$ BP; Savchenko 1999), indicate that settlement of the Eastern Urals area started much earlier than originally thought (Savchenko 2003). The chronology of the Early Neolithic of the region was also not well established, because most sites excavated from this period had admixtures originating from other periods. In addition, only few ${ }^{14} \mathrm{C}$ dates were available. Some of these dates came from uncertain archaeological contexts; others are not consistent with the typological dating of the pottery assemblages. Here, we present the results of interdisciplinary research for 2 peat sites: Varga-2 at the Shigir peat bog, and Beregovaya-2 at the Gorbunovo mire. Varga-2 is located at the western part of the Shigir bog (Figure 1B) and produced an Early Neolithic layer. Beregovaya-2 is situated at the northeastern shore of the Gorbunovo paleolake (Figure 1C) and produced 5 cultural layers dating to, respectively, the Early, Middle, and Late Mesolithic, the Early Neolithic, and the Chalcolithic. Our investigations on these sites involved geochronology, archaeology, and paleoenvironmental studies. The main goal was to obtain reliable chronological data for the Mesolithic and Early Neolithic periods in this region, and to reconstruct the settlement history on the shores of the 2 lakes during the Early to Middle Holocene.

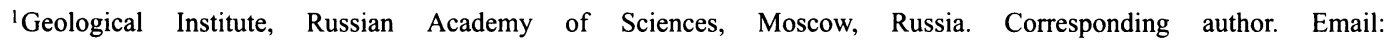
n_zaretskaya@inbox.ru.

${ }^{2}$ Schleswig-Holstein Archaeological Landsmuseum, Schloss Gottorf, Germany.

${ }^{3}$ Department of Pre- and Protohistory, University of Greifswald, Germany.

${ }^{4}$ Sverdlovsk Regional Museum, Ekaterinburg, Russia.

${ }^{5}$ Institute of Archaeology, Russian Academy of Sciences, Moscow, Russia.

(C) 2012 by the Arizona Board of Regents on behalf of the University of Arizona Proceedings of the 6th International Radiocarbon and Archaeology Symposium, edited by E Boaretto and N R Rebollo Franco RADIOCARBON, Vol 54, Nr 3-4, 2012, p 783-794 


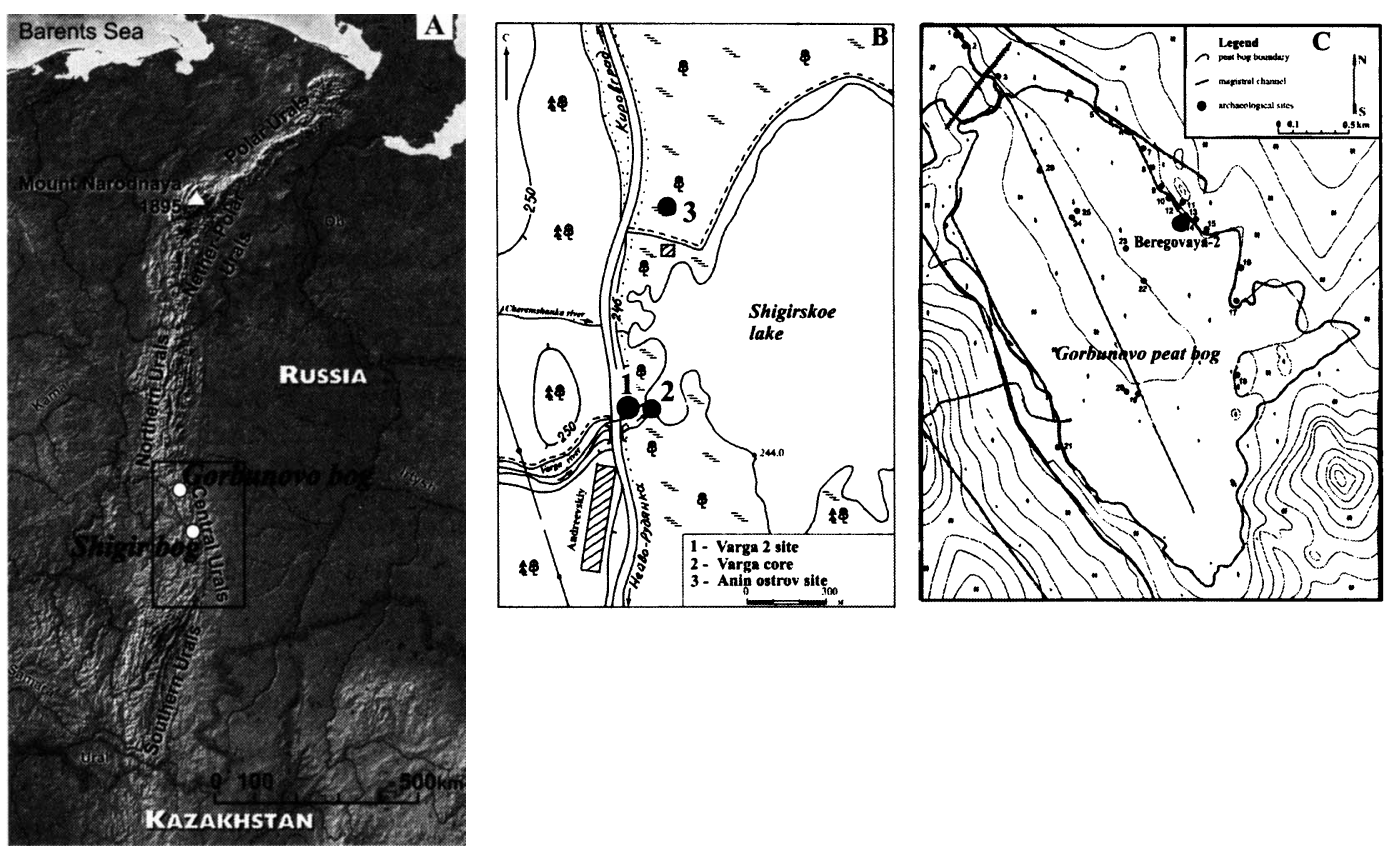

Figure 1 A) Study area: Central Ural Mountains with dots indicating Shigir and Gorbunovo peat bogs. B) map of the Shigir bog with sampling sites Varga-2, Varga core, and Anin ostrov indicated; C) map of the Gorbunovo peat bog with the Beregovaya-2 site indicated.

\section{STUDY AREA}

The Shigir and Gorbunovo peat bogs are both located in the Middle Urals region (Figure 1A).

\section{Varga-2 Site}

The Varga-2 site is situated in the western part of the Shigir peat bog, $\sim 90 \mathrm{~km}$ to the north-northeast from Ekaterinburg (Figure 1B). The Shigir peat bog contains 68 archaeological sites, most of them distributed on the shores and "islands" of the Shigir paleolake, with cultural layers mainly accumulated in the coastal zone. Unfortunately, most of the Shigir peat bog had been destroyed during gold mining at the end of 19th century. A large number of beautiful wood and bone artifacts from the Stone Age were found at that time (Savchenko 1999). In 2004, M G Zhilin and S N Savchenko investigated part of the Varga-2 site, which is located about $120 \mathrm{~m}$ from the modern lake shore, and observed an undisturbed cultural layer. This was a good opportunity to obtain sample material for ${ }^{14} \mathrm{C}$ dating and paleoenvironmental studies (Zaretskaya 2007; Zaretskaya and Uspenskaya 2007).

The stratigraphy of the excavation trench at Varga- 2 can be described from top to bottom as follows (Figure 2): 1) peaty turf $(10-20 \mathrm{~cm}) ; 2)$ surface dump $(20 \mathrm{~cm}) ; 3)$ brown peat with wood remnants $(60-110 \mathrm{~cm})$, in this layer old Varga River channels are identified; 4) dark-gray loam with quartz and slate-stone fragments $(30 \mathrm{~cm})$, Varga River deposits; 5) dark-brown peat with wood detritus, changing into peat containing cane (Phragmites communis) $(20 \mathrm{~cm}) ; 6)$ dark-olive detrital gyttja (50-70 $\mathrm{cm})$; 7) gray gyttja with wood detritus and dispersed charcoal $(20-30 \mathrm{~cm}) ; 8)$ beige gyttja with small shells $(20 \mathrm{~cm}) ; 9)$ blue-gray clay with gravel and stones, this is the bottom of the paleolake. 

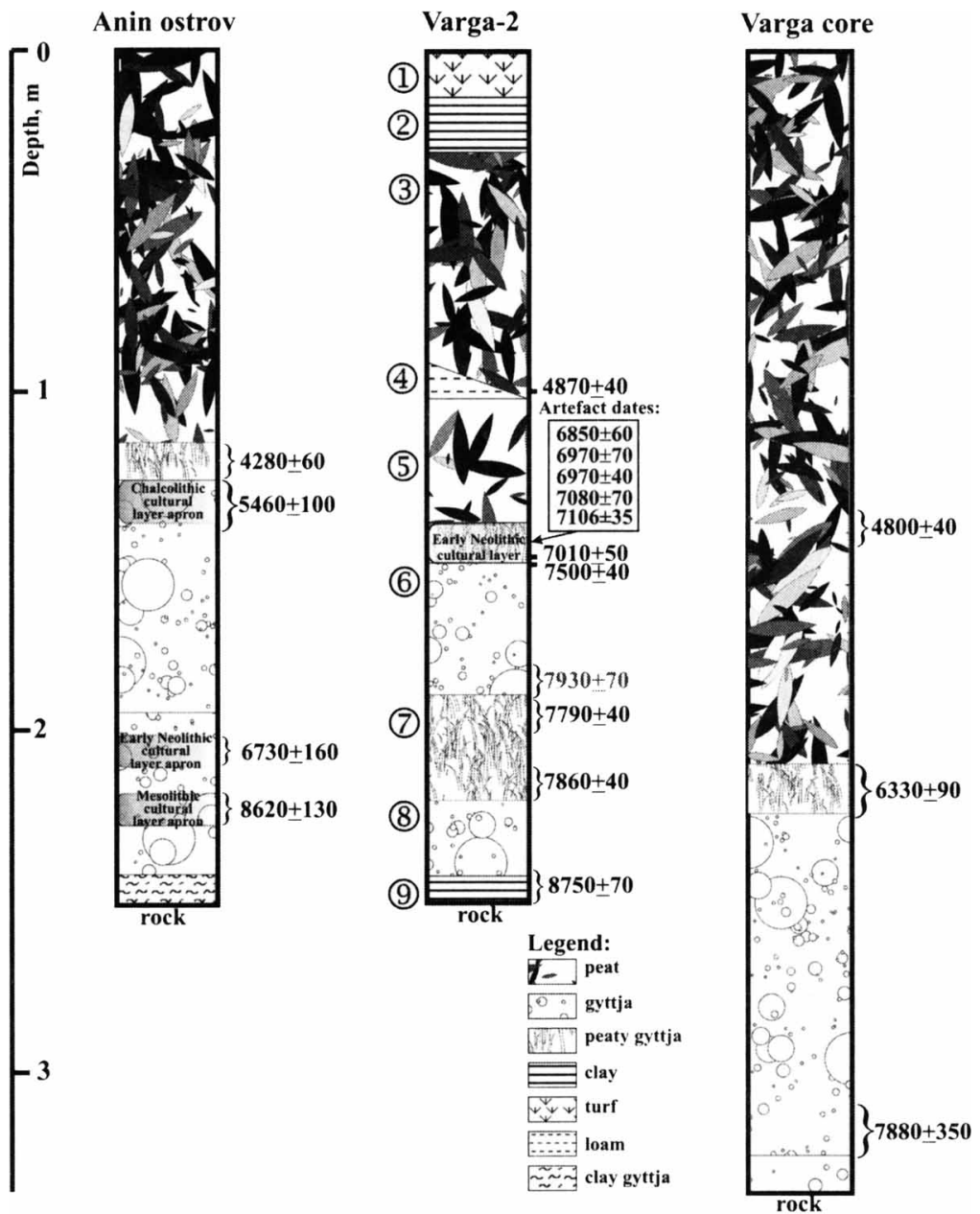

Figure 2 Dated sections at the Shigir peat bog: Anin ostrov, Varga-2 (within the excavation pit), and Varga core (near the excavation area). Dates obtained on artifacts from the cultural layer (bottom of layer 5) are indicated with a rectangle.

Only 1 cultural layer (Early Neolithic) occurs in situ in layer 5 (dark-brown peat) and contains fireplace remains, ceramic fragments of different types, stone and bone artifacts, and animal bones (Zhilin and Savchenko 2007). Five ${ }^{14} \mathrm{C}$ dates for these artifacts are available, ranging from 6850 to 7106 BP (Table 1).

Table 1 Radiocarbon dates of the Shigir (Varga-2 site, Varga core, Anin ostrov site) and Gorbunovo (Beregovaya-2 site) peat bogs: sections and individual samples.

\begin{tabular}{lllll}
\hline \multicolumn{1}{c}{ Dated material } & Sample position & Lab code & Age BP & \multicolumn{1}{c}{ Age cal BC } \\
$1 \sigma$
\end{tabular}


Table 1 Radiocarbon dates of the Shigir (Varga-2 site, Varga core, Anin ostrov site) and Gorbunovo (Beregovaya-2 site) peat bogs: sections and individual samples. (Continued)

\begin{tabular}{|c|c|c|c|c|c|}
\hline & Dated material & Sample position & Lab code & Age BP & $\begin{array}{l}\text { Age cal BC } \\
1 \sigma\end{array}$ \\
\hline 5 & Peaty gyttja & Varga-2 sect., $-190 /-200 \mathrm{~cm}$ & GIN-13863 & $7790 \pm 40$ & $6658-6589$ \\
\hline 6 & Peat & Varga- 2 sect., $-210 /-220 \mathrm{~cm}$ & GIN-13864 & $7860 \pm 40$ & $\begin{array}{l}6754-6718 \\
6712-6642\end{array}$ \\
\hline 7 & $\begin{array}{l}\text { Olive-colored detri- } \\
\text { tal gyttja }\end{array}$ & Varga-2 sect., $-240 /-250 \mathrm{~cm}$ & GIN-13865 & $8750 \pm 70$ & $7940-7676$ \\
\hline 8 & Peat & Varga core, $-130 /-140 \mathrm{~cm}$ & GIN-13866 & $4800 \pm 40$ & $3587-3529$ \\
\hline 9 & Peaty gyttja & Varga core, $-210 /-225 \mathrm{~cm}$ & GIN-13867 & $6330 \pm 90$ & $5381-5216$ \\
\hline 10 & Beige gyttja & Varga core, $-310 /-325 \mathrm{~cm}$ & GIN-13868 & $7880 \pm 350$ & $7189-6426$ \\
\hline 11 & Peaty gyttja & Anin ostrov, $-115 /-126 \mathrm{~cm}$ & GIN-13869 & $4280 \pm 60$ & $\begin{array}{l}3011-2977 \\
2943-2870\end{array}$ \\
\hline 12 & Algae gyttja & Anin ostrov, $-126 /-140 \mathrm{~cm}$ & GIN-13870 & $5460 \pm 100$ & $4405-4230$ \\
\hline 13 & Cyanofycaea gyttja & Anin ostrov, $-198 /-213 \mathrm{~cm}$ & GIN-13871 & $6730 \pm 160$ & $5760-5486$ \\
\hline 14 & $\begin{array}{l}\text { Organo-mineral } \\
\text { gyttja }\end{array}$ & Anin ostrov, $-213 /-228 \mathrm{~cm}$ & GIN-13872 & $8620 \pm 130$ & $7830-7527$ \\
\hline 15 & Chip & Varga-2 Sq.m. 14, c.l. II & GIN-12990 & $6850 \pm 60$ & $5786-5667$ \\
\hline 16 & Small charred plank & Varga-2 Sq.m. 9, c.l. II & GIN-13852 & $: 40$ & 5789 \\
\hline 17 & Small charred plank & Varga-2 Sq.m. 5/9, c.1. I/II & GIN-13849 & $0 \pm 70$ & 5772 \\
\hline 18 & charred half-timber & Varga-2 Sq.m. 8, c.1, II & GIN-13855 & $7080 \pm 70$ & -5892 \\
\hline 19 & $\begin{array}{l}\text { Charred remain on a } \\
\text { rim fragment }\end{array}$ & Vessel 3, c.l. II & AAR-14837 & $7106 \pm 35$ & $\begin{array}{l}6020-5980 \\
5945-5925\end{array}$ \\
\hline \multicolumn{6}{|c|}{ Gorbunovsky peat bog } \\
\hline 20 & $\begin{array}{l}\text { Pick-axe insert (elk } \\
\text { antler) }\end{array}$ & Sq.m. $56,-278 \mathrm{~cm}$, c.l. II & AAR-14548 & $7278 \pm 34$ & $\begin{array}{l}6211-6137 \\
6110-6083\end{array}$ \\
\hline 21 & $\begin{array}{l}\text { Charred residue on a } \\
\text { koshkino-type sherd }\end{array}$ & Sq.m. $60,-288 \mathrm{~cm}$, c.1. II & KIA-42074 & $7325 \pm 40$ & $\begin{array}{l}6232-6203 \\
6146-6101\end{array}$ \\
\hline 22 & $\begin{array}{l}\text { Charred remain on a } \\
\text { rim sherd }\end{array}$ & Sq.m. 93, c.l.II, $-284 /-286 \mathrm{~cm}$ & AAR-14833 & $7320 \pm 38$ & $6230-6100$ \\
\hline 23 & Trackway, plank 3 & Sq.m. $32,-322 /-332 \mathrm{~cm}$, c.l. III & GIN-14134 & $7960 \pm 30$ & $\begin{array}{l}7028-6930 \\
6921-6877\end{array}$ \\
\hline 24 & Elk scapula knife & Sq.m. $70,-294 /-300 \mathrm{~cm}$, c.l. III & AAR-14549 & $7989 \pm 36$ & $\begin{array}{l}6972-6911 \\
6884-6829\end{array}$ \\
\hline 25 & Trackway, plank 5 & Sq.m. $58,-321 /-325 \mathrm{~cm}$, c.l. III & GIN-14133 & $7990 \pm 30$ & $\begin{array}{l}6971-6912 \\
6884-6830\end{array}$ \\
\hline 26 & $\begin{array}{l}\text { Trackway, plank } \\
\text { fragment }\end{array}$ & Sq.m. $40,-325 /-330 \mathrm{~cm}$, c.l. III & GIN-14087 & $7990 \pm 40$ & $\begin{array}{l}7042-6983 \\
6973-6911 ; \\
6885-6829\end{array}$ \\
\hline 27 & Thin burnt trunk & Sq.m. $5,-303 /-309 \mathrm{~cm}$, c.l. III & GIN-14085 & $8120 \pm 50$ & $7144-7057$ \\
\hline 28 & Burnt pine stake & $\begin{array}{l}\text { Sq.m. } 3-4,-309 /-313 \mathrm{~cm} \text {, bot- } \\
\text { tom of c.l. III }\end{array}$ & GIN-14086 & $8350 \pm 40$ & $\begin{array}{l}7490-7446 \\
7414-7356\end{array}$ \\
\hline 29 & $\begin{array}{l}\text { Binding of a net } \\
\text { sinker, willow bark }\end{array}$ & Sq.m. 85 , c.l. IV, $-380 \mathrm{~cm}$ & AAR-14834 & $8405 \pm 40$ & $7540-7460$ \\
\hline 30 & $\begin{array}{l}\text { Binding of a net } \\
\text { sinker, willow bark }\end{array}$ & Sq.m. $46,-364 /-373 \mathrm{~cm}$, c.l. IV & KIA-42075 & $8445 \pm 50$ & 7569-7494 \\
\hline 31 & Wooden stake & $\begin{array}{l}\text { Sq.m. } 24 \text {, horiz., }-340 /-346 \mathrm{~cm} \text {, } \\
\text { c.l. IV }\end{array}$ & GIN-14137 & $8490 \pm 40$ & $7578-7535$ \\
\hline 32 & Worked pla & Sq.m. 7, horiz., $-368 \mathrm{~cm}, \mathrm{IV}$ & GIN-14089 & $8670 \pm 40$ & $7683-7601$ \\
\hline 33 & Elk antler & $\begin{array}{l}\text { Sq.m. } 48-49 \text {, horiz., }-373 /-377 \\
\text { cm, c.l. IV }\end{array}$ & GIN-14207 & $8840 \pm 70$ & $\begin{array}{l}8198-8110 \\
8002-7821\end{array}$ \\
\hline 34 & $\begin{array}{l}\text { Worked larch } \\
\text { branch }\end{array}$ & $\begin{array}{l}\text { Sq.m. } 6 \text {, horiz., }-358 /-362 \mathrm{~cm} \text {, } \\
\text { c.l. IV }\end{array}$ & GIN-14090 & $8970 \pm 60$ & $\begin{array}{l}8278-8183 ; \\
8042-7994\end{array}$ \\
\hline 35 & Stake, larch & Sq.m. 43 , horiz., $-378 \mathrm{~cm}$, IV & GIN-14136 & $9010 \pm 40$ & $8278-8234$ \\
\hline 36 & Red deer scapula & Sq.m. 41 , horiz., $-370 \mathrm{~cm}, \mathrm{c} .1$. IV & GIN-14208 & $10,200 \pm 100$ & $10,140-9754$ \\
\hline 37 & Stake, larch & $\begin{array}{l}\text { Sq.m.7, sec. } 1,-371 /-379 \mathrm{~cm} \text {, } \\
\text { horiz., lake bottom, c.l. V }\end{array}$ & GIN-14088 & $9800 \pm 40$ & $9289-9253$ \\
\hline
\end{tabular}


Table 1 Radiocarbon dates of the Shigir (Varga-2 site, Varga core, Anin ostrov site) and Gorbunovo (Beregovaya-2 site) peat bogs: sections and individual samples. (Continued)

\begin{tabular}{|c|c|c|c|c|c|}
\hline & Dated material & Sample position & Lab code & Age BP & $\begin{array}{l}\text { Age cal BC } \\
1 \sigma\end{array}$ \\
\hline 38 & $\begin{array}{l}\text { Two elk bones from } \\
\text { the same sq. } \mathrm{m} \text {. }\end{array}$ & $\begin{array}{l}\text { Sq.m. } 48,-385 /-396 \mathrm{~cm} \text {, horiz., } \\
\text { lake bottom, c.l. V }\end{array}$ & GIN-14210 & $9830 \pm 70$ & $9356-9241$ \\
\hline 39 & Elk scapula knife & $\begin{array}{l}\text { Sq.m. } 21,-404 \mathrm{~cm} \text {, horiz., lake } \\
\text { bottom, c.l. V }\end{array}$ & KIA-42076 & $9835 \pm 50$ & $9316-9255$ \\
\hline 40 & Worked log, larch & $\begin{array}{l}\text { Sq.m. } 42-43,-378 /-376 \mathrm{~cm} \text {, } \\
\text { horiz., lake bottom, c.l. V }\end{array}$ & GIN-14135 & $9850 \pm 40$ & $9317-9266$ \\
\hline 41 & $\begin{array}{l}\text { Red deer scapula } \\
\text { knife preform }\end{array}$ & $\begin{array}{l}\text { Sq.m. } 60-72,-386 / 392 \mathrm{~cm} \text {, } \\
\text { horiz., lake bottom, c.l. V }\end{array}$ & GIN-14209 & $10,060 \pm 80$ & $9815-9446$ \\
\hline 42 & $\begin{array}{l}\text { Tool preform from a } \\
\text { tubular bone }\end{array}$ & $\begin{array}{l}\text { Sq.m. } 20,-408 \mathrm{~cm} \text {, horiz., lake } \\
\text { bottom, c.l. V }\end{array}$ & KIA-42077 & $9215 \pm 40$ & $8474-8337$ \\
\hline 43 & $\begin{array}{l}\text { Stake, larch-1 } \\
\text { (same construction) }\end{array}$ & Sq.m. $76,-412 /-461 \mathrm{~cm} ; \mathrm{c} .1 . \mathrm{V}$ & GIN-14251 & $8980 \pm 90$ & $\begin{array}{l}\text { 8285-8170; } \\
\text { 8116-8053; } \\
8047-7981\end{array}$ \\
\hline 44 & $\begin{array}{l}\text { Stake, larch-2 } \\
\text { (same construction) }\end{array}$ & Sq.m. $76,-397 /-434 \mathrm{~cm}$; c.l. V & GIN-14249 & $9230 \pm 50$ & $\begin{array}{l}8489-8419 \\
8410-8346\end{array}$ \\
\hline 45 & $\begin{array}{l}\text { Stake, larch-3 } \\
\text { (same construction) }\end{array}$ & Sq.m. $76 .-395 /-430 \mathrm{~cm}$; c.l. V & GIN-14250 & $9230 \pm 60$ & $\begin{array}{l}8491-8417 \\
8414-8344\end{array}$ \\
\hline 46 & Sedge peat & $\begin{array}{l}\text { Sec.1, layer } 3,-230 \mathrm{~cm} \text {, c.l.III, } \\
\text { bottom }\end{array}$ & GIN-14080 & $8360 \pm 40$ & $\begin{array}{l}7511-7449 \\
7410-7362\end{array}$ \\
\hline 47 & Gyttja & $\begin{array}{l}\text { Sec. } 1 \text {, layer } 4 \text {, between c.l. III } \\
\text { and IV, }-238 \mathrm{~cm}\end{array}$ & GIN-14081 & $8620 \pm 40$ & $7654-7585$ \\
\hline 48 & Gyttja & Sec.1, layer 5, c.l. IV, top & GIN-14082 & $8970 \pm 40$ & $8275-8202$ \\
\hline 49 & Gyttja & $\begin{array}{l}\text { Sec. } 1 \text {, layer } 5 \text {, bottom, below c.l. } \\
\text { IV, }-370 /-375 \mathrm{~cm}\end{array}$ & GIN-14083 & $9140 \pm 40$ & $8349-8285$ \\
\hline 50 & Peaty gyttja & $\begin{array}{l}\text { Sec.1, layer } 6 \text {, c.l. V }-377 / \\
-380 \mathrm{~cm}\end{array}$ & GIN-14084 & $9610 \pm 40$ & $\begin{array}{l}9011-8912 \\
8904-8845\end{array}$ \\
\hline 51 & Sphagnum peat & $\begin{array}{l}\text { Sec.2, layer } 2,20 \mathrm{~cm} \text { above c.l. } \\
\text { II, }-261 \mathrm{~cm}\end{array}$ & GIN-14124 & $6390 \pm 110$ & $5478-5295$ \\
\hline 52 & Sphagnum peat & $\begin{array}{l}\text { Sec. } 2 \text {, layer } 2,5 \mathrm{~cm} \text { above c.l. II, } \\
-281 \mathrm{~cm}\end{array}$ & GIN-14125 & $6990 \pm 40$ & $\begin{array}{l}5975-5950 \\
5918-5837\end{array}$ \\
\hline 54 & Sedge peat & $\begin{array}{l}\text { Sec.2, layer } 3,-323 \mathrm{~cm}, \mathrm{c} .1 . \mathrm{III}, 1 \\
\text { trackway level }\end{array}$ & GIN-14126 & $7990 \pm 40$ & $\begin{array}{l}7042-6983 \\
6973-6911 \\
6885-6829\end{array}$ \\
\hline 55 & Sedge peat & $\begin{array}{l}\text { Sec. } 2 \text {, layer } 3 \text {, bottom below c.l. } \\
\text { III, }-335 \mathrm{~cm}\end{array}$ & GIN-14127 & $8190 \pm 40$ & $\begin{array}{l}7261-7225 \\
7193-7128\end{array}$ \\
\hline 56 & Cane peat & $\begin{array}{l}\text { Sec.2, layer 3, bottom below } \\
-342 \mathrm{~cm}\end{array}$ & GIN-14128 & $8200 \pm 40$ & $\begin{array}{l}\text { 7301-7219; } \\
7199-7139\end{array}$ \\
\hline 57 & Gyttja & Sec.2, layer 4 , top, $-345 \mathrm{~cm}$ & GIN-14129 & $8480 \pm 40$ & 7575-7530 \\
\hline 58 & Gyttja & $\begin{array}{l}\text { Sec. } 2 \text {, layer } 5,-368 \mathrm{~cm}, \mathrm{c} .1 . \mathrm{IV} \text {, } \\
\text { top }\end{array}$ & GIN-14130 & $8520 \pm 100$ & $7651-7474$ \\
\hline 59 & Gyttja & $\begin{array}{l}\text { Sec. } 2 \text {, layer } 5,-380 \mathrm{~cm} \text {, c.l. IV, } \\
\text { bottom }\end{array}$ & GIN-14131 & $9170 \pm 90$ & $8475-8289$ \\
\hline 60 & Peaty gyttja & Sec.2, layer $6,-403 \mathrm{~cm}, \mathrm{c} .1 . \mathrm{V}$ & GIN-14132 & $9210 \pm 40$ & $8469-8328$ \\
\hline 61 & Peaty gyttja & Sq.m. $35,-371 \mathrm{~cm}$, layer 6 , c.l. V & GIN-14140 & $9390 \pm 40$ & $8724-8624$ \\
\hline
\end{tabular}

\section{Beregovaya-2 Site}

Beregovaya-2, discovered in 1944, is located on the rocky cape of the northeastern part of the Gorbunovo peat bog, $5 \mathrm{~km}$ southwest from the city of Nizhniy Tagil (Figure 1C). The Gorbunovo peat bog contains 38 archaeological sites along the paleolake shores and in the bog, dating from the Mesolithic to Early Iron Age periods. In 2008, M G Zhilin and S N Savchenko discovered a wellstratified "peat-bog" part below the rocky cape of Beregovaya-2, including 5 cultural layers (Zhilin and Savchenko 2009). 
The stratigraphy of the excavation trench in this part of the peat bog encompasses the following layers (from top to bottom, Figure 3): 1) dark-brown decomposed peat $(40 \mathrm{~cm}) ; 2$ ) light-brown peat with wood logs $(70-120 \mathrm{~cm}) ; 3)$ dark-brown decomposed peat $(60-90 \mathrm{~cm})$; 4) gray-brown olivecolored detrital loose gyttja $(10 \mathrm{~cm}) ; 5)$ gray-brown detrital sticky gyttja $(5-25 \mathrm{~cm}) ; 6)$ brownish peaty gyttja with cane and typha leaves $(2-3 \mathrm{~cm}) ; 7)$ blue-gray clay with sand and stones, this is the bottom of the paleolake (observed thickness $50 \mathrm{~cm}$ ). We dated 2 continuous Holocene sections from the 2008 and 2009 excavation pits (Figure 3). Five cultural layers can be distinguished in the excavation trench, separated from each other by layers without artifacts (Figure 3).
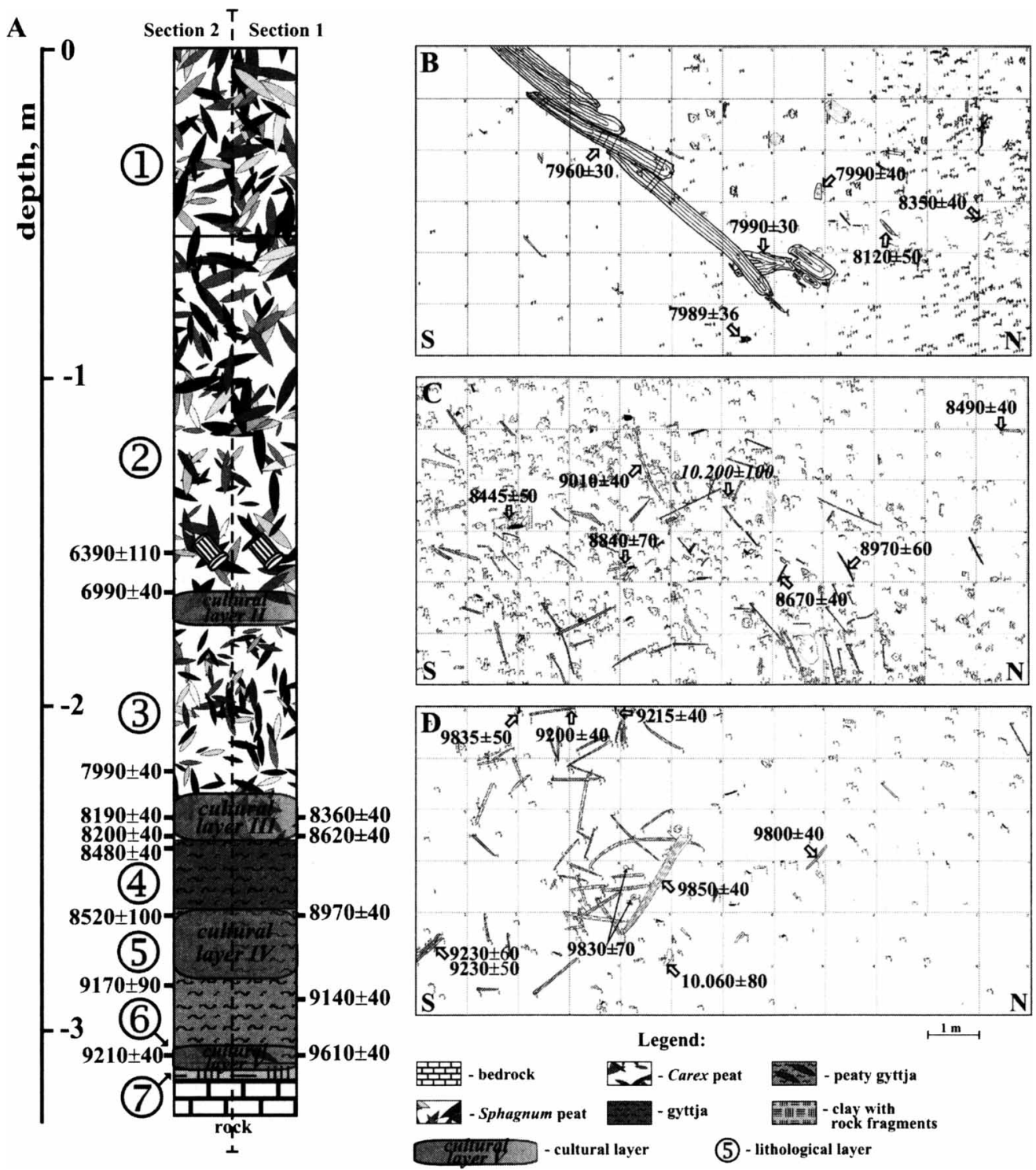

Figure 3 Beregovaya-2 site (Gorbunovo peat bog): A) summary section with dates on wetland deposits and lithology; dashed line is dividing sections 1 and 2 . Stratigraphy description is presented in the text; B) plan of cultural layer III with dates on artifacts; C) plan of cultural layer IV with dates on artifacts; D) plan of cultural layer V with dates on artifacts. 
Cultural layer I is located at the bottom part of layer 1 and contains few stone tools, animal bones, and fragments of ceramic of the Chalcolithic Ayat culture. We suppose that the layer represents the shoreline part of a Chalcolithic settlement existing on the rocky cape.

Cultural layer II is associated with the upper part of layer 3 in the northern part of the trench and with the bottom part of layer 2 in the southern part of the trench. It contains Early Neolithic ceramic fragments, stone, bone and antler tools, and animal bones. This represents the shoreline area of a settlement where some economic activities took place at the peaty, but rather dry, meadow-like shore in the northern part of the trench. Some refuse was discarded further into the swamp in the southern part of the trench, while the main settlement site occupied the rocky peninsula above it.

Cultural layer III is located in the bottom part of layer 3 and is related to Late Mesolithic activities. The lithic industry is typical for Eastern Urals Mesolithic sites; bone and antler tools are also present, but no ceramic fragments. The most interesting find is a well-preserved trackway (Figure 3B), composed of partly charred larch planks, placed on the mire surface.

Cultural layer IV is located in the upper part of layer 5 (Figure 3A) and is associated with the Middle Mesolithic period. Many stone artifacts (among them net sinkers with bark tapes) and bone and antler tools (arrowheads, knives, harpoons, even a pack containing 11 arrows) were found as well as many mammal, bird, and fish bones. In the southern part of the excavation trench, sharpened wooden stakes driven into lake bottom were discovered.

Cultural layer $\mathrm{V}$ is the oldest archaeological complex at this site. It is located directly on the bedrock (layer 7), partly in and under layer 6 (Figure 3A). Here, many sticks, 1 worked log, stone artifacts, and bone and antler artifacts (knives and harpoon fragments) were found. We suppose that this layer represents the earliest stage of Mesolithic settlement of this region.

\section{METHODS: RADIOCARBON DATING AND MACROFOSSIL ANALYSIS}

We used both conventional and accelerator mass spectrometry (AMS) methods for ${ }^{14} \mathrm{C}$ dating of wetland deposits (peat and gyttja) containing artifacts, and of the artifacts themselves (bones and bone tools, worked wood, sticks, log fragments, and charred crust adhering to pottery). All dates are presented in Table 1, with a selected number shown in Figures 2 and 3.

In the field, we sampled 3 sections from the Shigir peat bog ( 1 section from the Varga- 2 excavation trench, 1 core nearby, and 1 core near Anin Ostrov site $\sim 1 \mathrm{~km}$ from Varga-2) and 2 sections from the Gorbunovo peat bog (both from the Beregovaya-2 excavation trench). Artifacts for dating have been collected from the entire excavation area from all Mesolithic and Neolithic cultural levels.

Most of the samples were dated conventionally at the Geological Institute of the Russian Academy of Sciences in Moscow (laboratory code GIN), using a standard pretreatment procedure (Zaretskaya et al. 2001, 2005; Zaretskaya 2005, 2007). Wood, peat, and gyttja samples were pretreated and dated according to routine (AAA) procedure: after the cleaning of the sample in hot $5 \% \mathrm{HCl}$ dilution, it was washed with distilled water and then boiled for $20 \mathrm{~min}$ in $10 \%$ dilution of $\mathrm{NaOH}$. After that, samples were once again pretreated in $\mathrm{HCl}$ (hot $5 \%$ dilution or cold concentrated depending on sample type) and washed with distilled water.

Gyttjas provide reliable dates for estimating age of deposits enclosing Mesolithic and Neolithic cultural remains. The pretreatment procedure was just the same as for peat samples, except that the boiling in $\mathrm{NaOH}$ was longer $(25-30 \mathrm{~min})$. The $\delta^{13} \mathrm{C}$ values of gyttja samples range from $28 \%$ to $22 \%$, and the gyttja dates mostly match with artifact dates from the same stratigraphic layer. There- 
fore, we consider that no freshwater reservoir effect is observed in the Middle Ural bogs even at $>3 \mathrm{~m}$ depth.

The method of collagen extraction from bone samples consists mainly of long sample cleansing in $\mathrm{HCl}$ dilution under cold conditions. After the $\mathrm{HCl}$ pretreatment, the collagen was diluted and then centrifuged and dried out. Details of the procedure are described in Sulerzhitsky and Romanenko (1999).

A number of small samples were dated by AMS in Kiel, Germany (lab code KIA) and Aarhus, Denmark (lab code AAR). For calibration, we used OxCal v 3.10 (Bronk Ramsey 1995, 2001) and the IntCal04 calibration curve data (Reimer et al. 2004). The complex formation and chronology of the early Holocene layers of Beregovaya 2 caused problems in building an age-depth model; here we used the sum probability distribution calculated by OxCal to work with this data set. The results are shown in Figure 4.
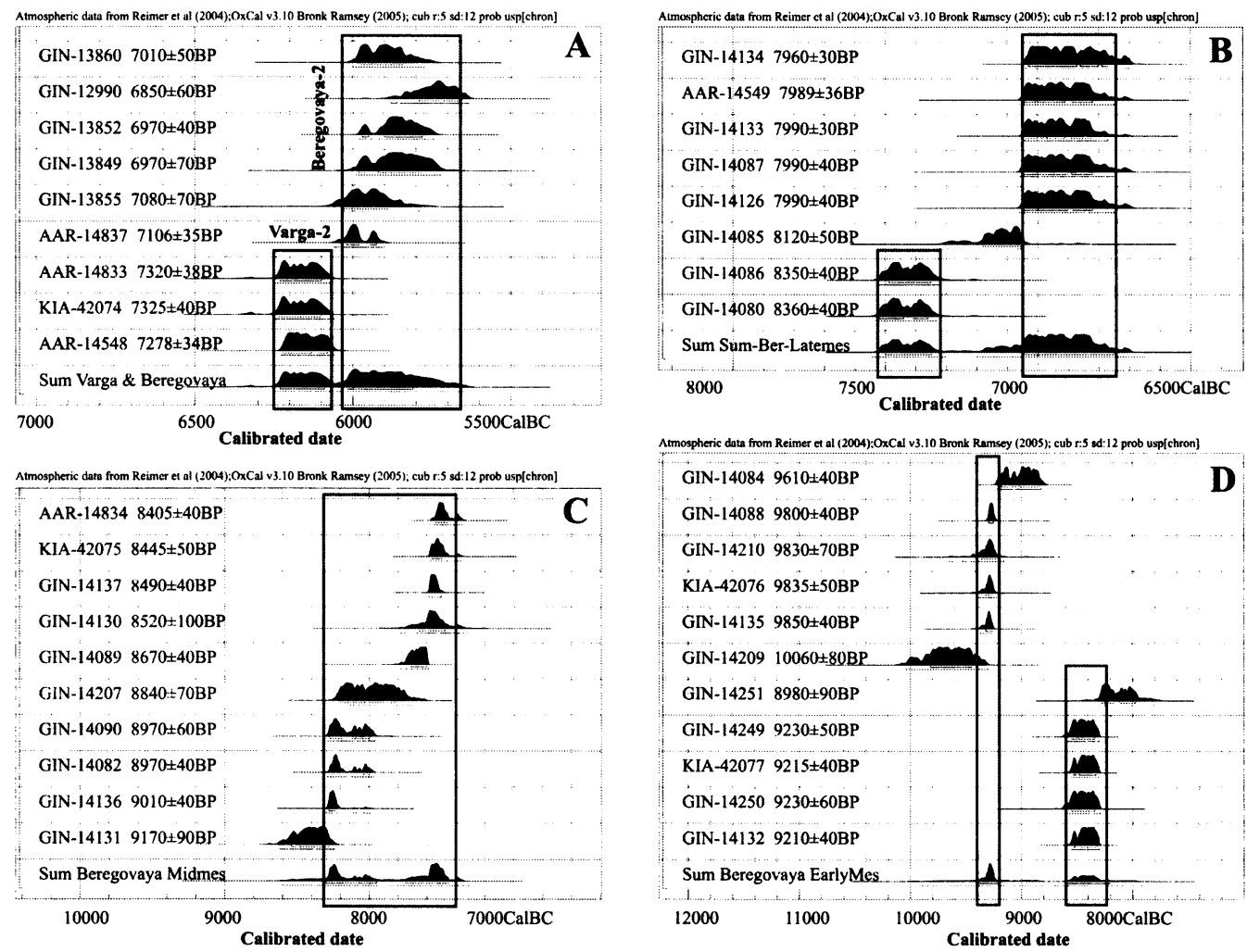

Figure 4 Calibrated ages and sum probability distribution of dates for cultural layers; blocks are bordering main cultural stages: A) Early Neolithic: Varga-2 site (6020-5800 cal BC) and Beregovaya-2 site (6230-6100 cal BC); B) Beregovaya-2 site, 2 stages of Late Mesolithic (7500-7350 and 7050-6750 cal BC); C) Beregovaya-2 site, Middle Mesolithic (8300-7450 cal BC); D) Beregovaya-2 site, Early Mesolithic, 2 stages (9400-9200 and 8600-8200 cal BC).

For paleoenvironmental reconstruction, we carried out plant macrofossil analysis for all dated peat and gyttja samples. This analysis provided not only the plant composition for the samples, but also the ecological conditions of sediment accumulation (depth, disturbance, cooling or still water, etc.), and the organic/mineral ratio of the sample. This enabled the reconstruction of the history of wetland 
sedimentation (accumulation of cultural and lithological layers) and local paleoenvironmental conditions (lake transgressions and regressions) at the archaeological sites (Zaretskaya and Uspenskaya 2007; Zaretskaya 2010).

\section{RESULTS AND DISCUSSION}

We obtained $19{ }^{14} \mathrm{C}$ dates for the Shigir peat bog and $42{ }^{14} \mathrm{C}$ dates for the Gorbunovo peat bog.

\section{Shigir Peat Bog}

The results from Shigir peat bog (Varga and Anin Ostrov) are shown in Figures 2 and 4 and Table 1. The dates for the wetland deposits represent almost in all cases the normal sequence from top to bottom. One inversion in the Varga-2 section (samples GIN-13862 and -13863) is possibly caused by redeposition during the paleolake transgression. The date obtained from the peaty gyttja enclosing artifacts is $7010 \pm 50 \mathrm{BP}(\mathrm{GIN}-13860)$; the 5 artifact dates are $7080 \pm 70 \mathrm{BP}$ (GIN-13855, charred half-timber under the Early Neolithic vessel remains), $6970 \pm 40 \mathrm{BP}$ (GIN-13852, charred plank), $6970 \pm 70$ BP (GIN-13849, charred plank), $6850 \pm 60$ BP (GIN-12290, chip), and $7106 \pm 35$ BP (AAR-14837, crust on early Neolithic sherd). All dates are in good agreement and demonstrate a short period of settlement of the Varga-2 site. The calibrated age of the Early Neolithic settlement of Varga-2 is $6020-5800 \mathrm{cal} \mathrm{BC}$, which is almost identical to the age of the early phase of the Upper Volga Early Neolithic culture (Zaretskaya and Kostyliova 2008; Hartz et al. 2012). In the Anin Ostrov site core, a date of $6730 \pm 160 \mathrm{BP}$ (GIN-13871, mixed algae gyttja) has been obtained for the level with Neolithic ceramics, which is younger than the Varga-2 set of dates. The ceramic sherd found there also appears later on typological grounds than pottery from Varga- 2 .

\section{Gorbunovo Peat Bog}

Results obtained for the Gorbunovo peat bog are shown in Figures 3 and 4 and Table 1. All dates obtained from wetland deposits show a normal sequence; no inversion has been observed. Most of the dates directly obtained on artifacts are in good agreement with the dates of the enclosing deposits. Nevertheless, there are some discrepancies and interesting peculiarities of site formation, which will be discussed below.

There are 3 AMS dates for the Early Neolithic layer II: $7278 \pm 34$ BP (AAR-14548, pick-axe insert made from elk antler); $7325 \pm 40 \mathrm{BP}$ (KIA-42074, charred crust from a ceramic fragment); and $7320 \pm 38$ BP (AAR-14833, charred crust from another ceramic fragment). The dates are in good agreement, so apparently no significant reservoir effect has affected the charred crust samples. The date from peat overlying this layer is $6990 \pm 40 \mathrm{BP}(\mathrm{GIN}-14125)$. The calibrated age of the Early Neolithic occupation of Beregovaya-2 site is 6230-6100 cal BC, which is significantly earlier than the Early Neolithic age of Varga-2 (Figure 4A). This indicates that here an earlier phase of the local Early Neolithic culture was excavated.

Nine dates, both conventional and AMS, were obtained for the Late Mesolithic layer III, 6 dates on artifacts and 3 on sedge peats (Table 1), which show quite a long duration of the habitation. The lowermost dated peat sample from section 1, which is close to the shore, provided an age of $8360 \pm 40$ BP (GIN-14080); the date of a burnt pine stake found at the same level is $8350 \pm 40 \mathrm{BP}$ (GIN14086). The date of a thin tree trunk $\sim 10 \mathrm{~cm}$ above is $8120 \pm 50 \mathrm{BP}$ (GIN-14085). The dates encompassing the chronological position of the layer III in section 2 are $8200 \pm 40 \mathrm{BP}$ (GIN-14128) and $7990 \pm 40 \mathrm{BP}$ (GIN-14126). There is a remarkable agreement between all dates for the wooden trackway fragments: $7960 \pm 30,7990 \pm 30$, and $7990 \pm 40 \mathrm{BP}(\mathrm{GIN}-14134,-14133$, and -14087 , respectively); an elk scapula knife: $7989 \pm 36$ BP (AAR-14549); and the upper part of the sedge 
peat: $7990 \pm 40 \mathrm{BP}(\mathrm{GIN}-14128)$. This set of results also proves excellent agreement between the conventional and AMS dates, indicating that no reservoir effect influenced the peat sample. The calendar age of the Late Mesolithic occupation corresponds to 2 periods: 7500-7350 and 7050-6750 cal BC (Figure 4B).

Twelve dates were obtained for cultural layer IV: 4 dates on pinkish Cyanophyceae gyttja; 7 dates on larch stakes, elk and red deer bones (conventional dates); and 2 on willow bark bindings of stone sinkers (AMS dates). Samples and dates of cultural layer IV from all age ranges and materials are evenly distributed over the excavation area (Figure $3 \mathrm{~A}$ and $\mathrm{C}$, Table 1). Therefore, we conclude that the habitation was continuous during the Middle Mesolithic. There is 1 outlier in the dates: 10,200 $\pm 100 \mathrm{BP}$ (GIN-14208), which stems from a red deer scapula. This might be the case of reuse of an older animal bone found by Middle Mesolithic people. The dates from the base of the gyttja layer without finds are older than those from the artifacts, indicating that habitation occurred when this layer had already partly formed, and people performed various economic activities above the shallow water near the lake shore, most probably using rafts or floating platforms. The calendar age of the Middle Mesolithic layer corresponds to the time range 8300-7450 cal BC.

For the Early Mesolithic cultural layer V, $12{ }^{14} \mathrm{C}$ dates were obtained. They correspond to 2 chronological groups (Figure 3A and D, Table 1). Most of the younger dates were lain farther away from the shore of the paleolake, while the older dates are situated closer to the shore. Another problem concerns the relationship between direct dates on artifacts and dates of the enclosing deposits: in the younger group, the dates are quite similar, but in the older group the enclosing peaty gyttja date is younger by about $200{ }^{14} \mathrm{C}$ yr. However, within each group, the dates agree well with each other.

Here, we propose the following paleogeographic scenario to explain the observed peculiarities of layer formation and chronology. During 9400-9200 cal BC, an Early Mesolithic settlement existed in the Beregovaya-2 area, on a dry surface of the shore of the paleolake. This is confirmed by data published earlier (Khotinsky 1977): in a core in the middle of the Gorbunovo peat bog a peat horizon underlying pinkish gyttja was identified between the early Holocene layers, i.e. there was a dry period in the history of the bog. After that, about $9000-8900$ cal BC, a lake transgression started to flood the settlement area, and the peaty gyttja with abundant cane (Phragmites communis) remnants was deposited. At this time, there was a hiatus in the Early Mesolithic settling of Beregovaya-2. Then, a regression of the lake took place, and during the second stage of the Early Mesolithic occupation, about $8600-8200$ cal BC, people most probably lived on the shore, and the cultural layer deposited in the littoral zone. Subsequently, a large transgression flooded the coastal area, which explains the archaeologically sterile layer (the lower part of pinkish gyttja) covering the cultural level V. After that, people came back again during the Middle Mesolithic, and the settlement of Beregovaya-2 continued from 8300 to $7450 \mathrm{cal} \mathrm{BC}$ (see above). The next lake transgression flooded the coastal area of the site and deposited a layer of olive-colored gyttja. The following settlement phase occurred during the late Mesolithic in 7500-6750 cal BC. Since that time, the transformation of the lake into a swamp started. Another gap in the settlement history coincides with the final Mesolithic period, and in the very beginning of the Neolithic, $\sim 6230-6100 \mathrm{cal} \mathrm{BC}$, when people again occupied both the rocky promontory and the dry peat surface below it.

\section{CONCLUSIONS}

Interdisciplinary studies at 2 peat bog archaeological sites in the Middle Urals, Varga- 2 and Beregovaya-2, including ${ }^{14} \mathrm{C}$ dating, archaeological and plant macrofossil analysis, enabled for the first time to determine the age of several stages of the Mesolithic and the early stage of the Neolithic of this region. An absence of reliable ${ }^{14} \mathrm{C}$ dates had, by the end of the 20th century, led to a wrong con- 
clusion that the initial Holocene settlement of the region occurred only during the Late Mesolithic (Serikov 2000). As our study was able to show the Mesolithic occupation of the Middle Urals area started already from the very beginning of the Holocene, contemporaneous with the forest zone of eastern Europe. A well-developed Mesolithic stone and bone industry, characterized by wise use of all available raw materials and by a high technological level, existed here already during the first half of the Holocene. Lithic tools are accompanied by various bone and antler tools and weapons, as well as wooden artifacts, including spears, javelins, arrow shafts, leister points, and others. Various bone arrowheads, harpoons, daggers, knives, perforators, and other tools from all 3 Mesolithic phases indicate a very high level of bone working. Composite weapons with slots for flint insets are present, supplemented with microblade insets and cores for their production. Many bone weapons are ornamented. The trackway to the lake shore over swamp from the upper Mesolithic layer at Beregovaya-2 is a perfect example of highly sophisticated woodwork and adaptation to local environment. Also of special interest is a large series of polished stone tools probably used for wood cutting, observed in the Middle Mesolithic layer. Such tools from mineral soil sites were usually treated as Neolithic artifacts (Serikov 2000), but they turned out to be much older. Fragments and preforms of such tools from the lowermost Mesolithic layer indicate the presence of this technology in the Middle Urals area at the very beginning of the Holocene. Such a phenomenon was earlier observed on the Upper Volga (Zhilin 2006, 2009), while in central and northern Europe polished wood cutting tools emerge much later.

According to our results, the introduction of pottery, which marks the transition from the Mesolithic to the Neolithic (Eastern terminology) in the region under study, started slightly earlier than in the forest zone of eastern Europe. This important result needs further investigation (Hartz et al. 2012). It is also interesting to note that ceramics of different types were found in the same layer and dated to a very short chronological interval at both sites. There are discussions about the chronological and typological relations of both pottery styles. Our study shows that 4 types of early Neolithic ceramics occur more or less synchronous in the Middle Urals area. A further important conclusion is the positive evidence for the use of composite projectile points with slots for flint insets in the Early Neolithic of the region, as indicated by finds of fragments of such bone artifacts at both sites. Earlier it was considered (without any dates available) that all composite weapons and microblade insets belong to the Mesolithic (Serikov 2000). The problem of the transition from the Mesolithic to the Neolithic in the Urals region is presently a subject of discussion, and the new reliable series of ${ }^{14} \mathrm{C}$ dates presented here provide a good framework for further research. The consistency of dates obtained from various organic materials (wood, herbivorous bones, charred remains from sherds) shows that there is no reservoir effect affecting the studied samples.

\section{ACKNOWLEDGMENTS}

We would like to thank Olga N Uspenskaya from the Peat Geology Research and Manufactory Association Vereya, Moscow region) for her kind help in estimating the plant macrofossil composition of our wetland samples. We thank Pavel Kosintsev from the Institute of Plant and Animal Ecology, Ural Division of RAS, Ekaterinburg, for the determination of animal bones from Varga-2 and Beregovaya-2. Finally, we would like to thank Henny Piezonka for very helpful comments on an earlier draft of this paper.

\section{REFERENCES}

Bronk Ramsey C. 1995. Radiocarbon calibration and analysis of stratigraphy: the $\mathrm{OxCal}$ program. Radiocarbon 37(2):425-30.

Bronk Ramsey C. 2001. Development of the radiocarbon calibration program. Radiocarbon 43(2A):355-63.

Hartz S, Kostyleva E, Piezonka H, Terberger T, Tsyden- 
ova N, Zhilin MG. 2012. Hunter-gatherer pottery and charred residue dating: new results on early ceramics in the north Eurasian forest zone. Radiocarbon, these proceedings.

Khotinsky NA. 1977. The Holocene of the Northern Eurasia. Moscow. Nauka. 198 p. In Russian.

Reimer PJ, Baillie MGL, Bard E, Bayliss A, Beck JW, Bertrand CJH, Blackwell PG, Buck CE, Burr GS, Cutler KB, Damon PE, Edwards RL, Fairbanks RG, Friedrich M, Guilderson TP, Hogg AG, Hughen KA, Kromer B, McCormac G, Manning S, Bronk Ramsey C, Reimer RW, Remmele S, Southon JR, Stuiver M, Talamo S, Taylor FW, van der Plicht J, Weyhenmeyer CE. 2004. IntCal04 terrestrial radiocarbon age calibration, 0-26 cal kyr BP. Radiocarbon 46(3):1029-58.

Savchenko SN. 1999. The history of the formation of the collection of Shigir antiquities in Sverdlovsk regional museum. In: 120 Years of Archaeology of the Eastern Slope of the Urals. Part 1. Ekaterinburg: The Urals State University. p 46-53. In Russian.

Savchenko S. 2003. Colonization of the Middle-Eastern Urals area during the early Mesolithic: some approaches to the problem. In: Knutsson $\mathrm{H}$, editor. Pioneer Settlements and Colonization Processes in the Barents Region. Vuollerim Papers on Hunter-Gatherer Archaeology. Volume 1. Vuollerim. p 9-15.

Serikov YB. 2000. The Paleolithic and Mesolithic of the Middle Eastern Urals Area. Nizhnii Tagil. In Russian.

Sulerzhitsky LD, Romanenko FA. 1999. The "twilight" of the mammoth fauna in the Asiatic Arctic. Ambio 28: 251-5.

Zaretskaya NE. 2005. Radiocarbon and calendar chronology of multi-layer peat sites within the Upper Volga. In: Zhilin MG, editor. Stone Age of the Eastern Europe and Trans-Ural Forest Zone. Moscow: Academia. p 113-29. In Russian.

Zaretskaya NE. 2007. New data on stratigraphy and radiocarbon chronology of western part of Shigir bog in the Holocene. In: Zhilin MG editor. Peculiarities and Adaptation of North Eurasia Forest Zone Cultures in the Late Pleistocene - Early Holocene. Moscow: IA RAN. p 244-53. In Russian.

Zaretskaya NE. 2010. Chronology, lithology and history of development of Gorbunovsky peat bog in the Holocene. In: Abstracts of the III North Archaeological Congress. Chanty-Mansiisk. p 89-91. In Russian.

Zaretskaya NE, Kostyliova EL. 2008. Radiocarbon chronology of the Early period of Verhnevolzhskaya culture (Sakhtysh-2a case study). Russian Archaeology 1 : 94-105. In Russian.

Zaretskaya NE, Uspenskaya ON. 2007. Chronology, stratigraphy and environmental dynamic. In: Zhilin MG, Zaretskaya NE, Kosinskaya LL, Kosintsev PA, Panova NK, Savchenko SN, Chairkina NM. Varga-2: An Early Neolithic Site in the Middle Trans-Ural. A Case of Complex Study. Ekaterinburg: The Urals State University. p 35-9. In Russian.

Zaretskaya NE, Ponomareva VV, Sulerzhitsky LD, Zhilin MG. 2001. Radiocarbon studies of peat bogs: an investigation of South Kamchatka volcanoes and Upper Volga archeological sites. Radiocarbon 43(2):535-43.

Zaretskaya NE, Zhilin MG, Karmanov VN, Uspenskaya ON. 2005. Radiocarbon dating of wetland archeological sites. Geochronometria 24:117-31.

Zhilin MG. 2006. Das Mesolithikum im Gebeist zwischen den Flussen Wolga und Oka: einige Forschungsergebnisse der letzten Jahre. Praehistorische Zeitschrift 81(1):1-48.

Zhilin MG, Savchenko SN. 2007. Results of excavations of the site Varga 2 at Shigir peat bog. In: Zhilin MG, Zaretskaya NE, Kosinskaya LL, Kosintsev PA, Panova NK, Savchenko SN, Chairkina NM. Varga-2: An Early Neolithic Site in the Middle Trans-Ural. A Case of Complex Study. Ekaterinburg: The Urals State University. p 5-26. In Russian.

Zhilin MG, Savchenko SV. 2009. A "hoard" of bone arrowheads from the Mesolithic site Beregovaya 2 in Eastern Urals area. In: Davudov O, editor. Problems of Archaeology of Eurasia. Makhachkala. In Russian. 